\title{
The Extent and Determinants of Voluntary Disclosures in Annual Reports: Evidence from Banking and Finance Companies in Sri Lanka
}

\author{
N.L.E. Abeywardana ${ }^{1} \&$ K.M. Panditharathna ${ }^{1}$ \\ ${ }^{1}$ Department of Commerce and Management, University of Kelaniya, Sri Lanka \\ Correspondence: N.L.E. Abeywardana, Department of Commerce and Financial Management, University of \\ Kelaniya, Sri Lanka \\ Received: September 27, 2016 \\ Accepted: October 26, 2016 \\ Online Published: November 4, 2016 \\ doi:10.5430/afr.v5n4p147 \\ URL: http://dx.doi.org/10.5430/afr.v5n4p147
}

\begin{abstract}
Corporate disclosures are essential for every stakeholders. Hence, in excess of mandatory disclosures companies are voluntary disclosed information. The voluntary disclosure level is different from company to company and there may be some factors which are affect to this variation. Therefore, the objectives of this study are to identify the extent of voluntary disclosure level and its determinants. In order to achieve these objectives the study develop a voluntary disclosure index including 83 items and the nine sub categories which include in this index analyzed by employing content analysis in the annual reports of quoted public banking and finance companies for the time period of 2012 to 2015. Furthermore, this study analyze the selected variable to identify the determinants of voluntary disclosure level by employing panel data analysis. The study find that disclosures about general information, corporate environment, financial performance and risk management has more than $61 \%$ level and Corporate strategy, forward looking information, human and intellectual capital, competitive environment and outlook and corporate social responsibility information have less than $45 \%$ average in 2015 and it indicates that there is a much room for improvement in the context of voluntary disclosures. Furthermore, the study find that firm size, profitability, firm's age, leverage and board independence as determinants of voluntary disclosure level and among them firm size, profitability and firm's age have positive relationship and leverage and board independence has negative relationship.
\end{abstract}

Keywords: Content analysis, Panel data analysis, Mandatory disclosure, Voluntary Disclosure

\section{Introduction}

Corporate disclosures can be considered as an imperative notion in both developed and emerging capital markets. The range of corporate disclosure is enormous and it can be vary from non-disclosure to complete disclosure (Elliott and Jacobson, 1994). This Corporate disclosures consist with both mandatory and voluntary disclosures. Mandatory disclosures are disclosed by companies to compliance with statutory regulations and voluntary disclosures can be defined as the disclosures which is not mandated (Cooke, 1992). Therefore companies disclose voluntary information in excess of the mandatory information. Organizations who disclose more information have opportunity to obtain some benefits such as lower capital costs, gain investor confidence, and improve marketability of their shares (Meek et al., 1995, Kristandl and Bontis, 2007) and Corporate disclosure is vital for the users of financial statements in order to make informed decisions on the valuation and investment (Iatridis and Alexakis, 2012; Charumathi and Ramesh 2015). Further voluntary disclosures is a device which reduce the information gap in between insiders and the stakeholders. Furthermore, if management voluntary disclose information, then they will be able to enhance the credibility of their reporting among stakeholders. Therefore, due to the gravity of importance of voluntary disclosures researchers, national accounting bodies and all other stakeholders began to make their attentiveness on the voluntary disclosures provided by corporate bodies within last few decades.

However, the degree of providing voluntary accounting disclosures varies from firm to firm (Iatridis and Alexakis, 2012) and there are factors which influence to voluntary information in annual reports and it lead to have variation in the level of disclosure among companies (Nazli, 2008). It is true that mandatory disclosures essentially disclosed by firms as per regulatory requirements, therefore there will not be any motive factors to do so. However, without any statutory requirement organization disclose voluntary information. Therefore, it is very important to comprehend the extent of this voluntary disclosure level and the factors which affect to this voluntary disclosure level. 
Even though there are ample studies available internationally such as Cerf 1961; cooke 1992; Ahmed and Nicholls 1994; Wallace et.al. 1994; Meek et.al. 1995; Inchausti, 1997; Haniffa and Cooke 2002; Naser et.al. 2002; Gul, and Leung 2004; Leventis and Weetman, 2004; Barako et al. 2006; Huafang and Jianguo 2007; Lim et al. 2007; Abdullah and Ku Ismal 2008; Hossain and Hammami 2009; Ousama and Fatima; 2010; Iatridis and Alexakis, 2012; Al-Shammari, 2013; Charumathi and Ramesh 2015; Habbash et.al. 2016, only few published studies could be found in the area of voluntary disclosures in annual reports in Sri Lanka. Therefore with the identification of determinants, this study seek in depth analysis of voluntary disclosure level in Banking and Finance companies in Sri Lanka. Hence, this study formulated two objectives as; to examine the extent of voluntary disclosures in corporate annual reports in banking and finance companies and o identify the determinants of voluntary disclosure level in banking and finance companies.

By achieving these two objectives, this study contributes to understand the voluntary disclosure practices in annual reports of banking and finance companies and the motives of voluntary disclosures. Therefore, this study fill a gap on empirical studies in voluntary disclosures in annual reports in Sri Lankan companies and it lead to extent the Sri Lankan literature on voluntary disclosures in three ways. Firstly, the study add clarity to the ongoing voluntary disclosure debate from the perspectives of an emerging market. Secondly, this study provides the voluntary disclosure index which can be used by researchers for their future studies. Thirdly, the study used the panel data analysis and the researcher found very few studies which used panel data analysis to study the determinants of voluntary disclosures. This study not only contribute to the theoretical world but also to the practical world. Because based on the findings of this study, management of companies and regulatory bodies can identify the motives of voluntary disclosures and it will support to their decision making process. Further, this results would be essential to the existing and future investors.

The balance part of the paper is organized as follows. The next section consists with the prior research studies on voluntary disclosures and theoretical background. Methodology section explains the sample, population of the study, data and research method. Fourth section analyses the data, results and findings. Fifth section discuss the findings of the study with support from the prior studies and the lastly, the conclusion of the study presented.

\section{Literature Review and Hypothesis Development}

Since the work done by Cerf (1961) the topic of determinants of voluntary disclosures become more attractive and important study area among academicians and it caused to have substantial literature on the quality of voluntary disclosure level and the association between the voluntary disclosure level and the various determinants. Studies such as Naser et.al 2002; Barako et al. 2006; Ousama and Fatima; 2010; Al-Shammari, 2013 identified the level of voluntary disclosures and Studies such as Cerf 1961; cooke 1992; Ahmed and Nicholls 1994; Wallace et.al.1994; Meek et.al. 1995; Inchausti, 1997; Naser et.al. 2002; Gul and Leung 2004; Leventis and Weetman, 2004; Barako et.al 2006; Huafang and Jianguo 2007; Abdullah and Ku Ismal 2008; Iatridis and Alexakis, 2012; Charumathi and Ramesh 2015 attempt to identify the determinants of voluntary disclosures in various countries and in various industries.

Agency theory explain that why firms should and do disclose information and it provides theoretical perspective for this study. Agency theory developed by Ross 1973 and it was further studied and expanded by Jensen and Meckling in 1976. According to the agency theory, the disclosure by the companies tends to reduce the information asymmetry between external stakeholders and management. The management acts as agents to shareholders and the management is expected to act in the best interest of the shareholders and inform the shareholders through proper disclosures, the absence of which would increase the agency costs in the form of litigations and auditing expense (Charumathi and Ramesh 2015). Therefore one of the reason to have agency cost is imperfect information available to shareholders which do not adequate to make proper decisions. Hence, strength voluntary disclosure level will be affect to reduce the agency cost.

Hence, by taking the agency theory as theoretical foundation and with support of the literature all the hypothesis are developed for the study.

\subsection{Size}

Firm size can be identified as an important variable which affect to level of corporate disclosure. Agency problem can be efficiency controlled by small noncomplex organizations (Fama and Jensen 1983). Therefore it suggest that if the firm size is small then the agency cost also will be decreased. Therefore, to avoid this agency conflict, larger firms may disclose more voluntary information and this suggestion is supported by the studies Ahmed and Nicholls 1994; Souissi and Khlif 2012; Iatridis and Alexakis, 2012. Studies were explained the reasons behind to have this 
kind of relationship. Firms should incur more cost to prepare and disclose the information and it became financial burden to small firms, but large firms can incur that expenditure without burden (Naser et al. 2002). Furthermore, more than the small firms' larger firms rely on financial markets to enhance funds and therefore for that purpose they naturally required to disclose more information (Ahmed and Nicholls 1994). Therefore, Studies such as Cerf 1961; Ahmed and Nicholls 1994; Wallace et.al.1994; Inchausti, 1997; Naser et.al. 2002; Gul, and Leung 2004; Leventis and Weetman, 2004; Barako et.al 2006; Huafang and Jianguo 2007; Lim et al. 2007; Abdullah and Ku Ismal 2008; Hossain and Hammami 2009; Bhasin et.al. 2012; Uyar et.al. 2013; Habbash et.al. 2016 identified the positive relationship between firm size and corporate disclosure level. However studies such as Haniffa and Cooke 2002 identified that size is not a significant factor which determine the level of corporate disclosure.

Based on the theoretical and literature foundation the hypothesis is developed as;

H1: There is a positive relationship between firm's size and the voluntary disclosure level.

\subsection{Profitability}

From the perspective of the agency theory, in order to obtain personal advantages, the management of very profitable firm will use information (Inchausti, 1997).

Previous studies have provided mix results on the relationship between firm profitability and disclosures. Studies such as Wallace et.al. 1994; Haniffa and Cooke 2002; Naser et.al. 2002; Gul, and Leung 2004; Lim et al. 2007; Habbash et.al. 2016 identified the significant positive relationship among firm's profitability and corporate voluntary disclosures. Such a relationship exist because firms do not voluntary provide rich accounting disclosures when they are not performing well and firms that perform well voluntary disclose detailed accounting information (Iatridis and Alexakis, 2012). Furthermore, management of companies which has more profits motivated to disclose more information to support continuance of firm's position and to increase its compensation (Naser et.al. 2002).

However, studies such as Wallace et.al. 1994; Inchausti 1997, Barako et.al 2006; Abdullah and Ku Ismal 2008; Hossain and Hammami 2009 found that no relationship between firm's profitability and level of corporate disclosure.

Based on the agency theory expectations and supported literature, the hypothesis to be tested in the study is;

$\mathrm{H} 2$ : There is a positive relationship between firm's profitability and voluntary disclosure level.

2.3 Age

Prior studies made arguments in favor of negative relationship among firm's age and voluntary disclosures and as well as positive relationship. Haniffa and Cooke 2002 mentioned that, to enhance the confidence of investors who may think that new firm as risky and to reduce skepticism, newly listed companies need to disclose more information.

However, contradict with that argument Owusu-Ansah 1998 mentioned that older firms are disclose more information in their annual reports than younger firms. According to him younger firms are reluctant to disclose some certain information such as research expenditure, capital expenditure and product development due to the fear to loss of competitive advantage. But older firms believed that presenting of those information will not be affect to loss their competitive position. Further according to his argument the cost of disseminating information also high to the younger firms than older forms and also younger firms do not have required track records to rely on for public disclosure. Further, in his study he identified the positive association in between firm's age and disclosure level. Supporting to that argument Hossain and Hammami (2009) and Habbash et.al. (2016) found the positive relationship between firm's age and voluntary disclosure level.

However, Haniffa and Cooke 2002; Uyar et.al. 2013 identified that there is no relationship among firm's age and voluntary disclosure level.

Based on the above arguments which are made in favor of positive relationship, the hypothesis is developed as;

H3: there is a positive association between listing age of companies and the extent of voluntary disclosure of information.

\subsection{Leverage}

The problem of information asymmetry and agency cost exist in between creditors and company (Jensen and Meckling 1976). Therefore to cope with this problem management should disclose more information. This lead to have positive relationship with the leverage and voluntary disclosure level. Before providing any loans the lenders and creditors asked more information form the companies (Naser et.al. 2002), therefore the firms who have intention 
to obtain more debts disclosed more information in their annual reports. Findings of Hossain et al. 1994; Naser et.al. 2002; Lim et al. 2007 were supported to that theoretical expectation. However, opposed to that expectation Uyar et.al. 2013 and Habbash et.al. 2016 identified the negative relationship. Furthermore, Leventis and Weetman, 2004 identified that there is no relationship between leverage and the voluntary disclosure level.

However, based on the theoretical foundation the hypothesis is developed as;

H4: There is a positive relationship between firm's leverage and voluntary disclosure level.

\subsection{Ownership Concentration}

There may be high agency conflict when there is a wider spread of shares ownership (Fama and Jensen, 1983). Therefore to reduce this conflict, companies may voluntarily disclose more information. Hence, it leads to expect the positive relationship between ownership concentration and voluntary disclosure level. However, there are mixed results for this relationship. Studies such as, Haniffa and Cooke 2002 identified positive relationship and studies such as Hossain et.al. 1994; Barako et.al 2006; Lim et al. 2007identified negative relationship. Whilst Craswell and Taylor (1992) found no relationship between ownership structure and voluntary corporate disclosure.

However in line with agency theory expectation the hypothesis test on this regard is,

H5: There is a positive relationship between ownership concentration and voluntary disclosure level.

\subsection{Board Independence}

Fama and Jensen 1983 suggested that effective boards would be largely comprised of outside directors to ensure better monitoring of management. Therefore, more independence directors would be caused to reduce the agency conflict and it may be occur due to the disclosure of more voluntary information in the annual reports.

If non-executive independent directors are actually carrying on their monitoring role then they expect more disclosure level (Haniffa and Cooke 2002; Eng and Mark 2003) and independent directors have motivation to disclose information voluntary to protect their reputation (Lim et.al. 2007). Therefore, proportion of independent directors are positively related to the board's ability to influence disclosure (Beasley 1996). Therefore it lead to have positive relationship between board independence and voluntary disclosure level. Huafang and Jianguo 2007; Uyar et.al. 2013 identified positive relationship between board independence and voluntary disclosure level. Hoewever, contradict with those results Eng and Mark 2003; Gul and Leung, 2004; Barako et.al 2006 found the negative relationship among board independence and voluntary disclosure level some others found no significant association (Forker, 1992; Haniffa and Cooke, 2002; Habbash et.al. 2016).

Therefore, based on the prior studies and with back of agency theory the hypothesis is developed as;

H6: There is a positive relationship between board independence and voluntary disclosure level

\section{Methodology}

This section focuses the mechanism which used to achieve two research objectives of this study. Therefore, this explains the population and sample of the study, data and research method.

All quoted public banking and finance companies were used as the population of this study. Currently 62 companies are registered under the banking, finance and insurance sector in Colombo Stock Exchange (CSE). Some items which include in voluntary disclosure index cannot be applied to non-financial companies. Therefore, the study selected only the banking and finance companies. it All the insurance companies and the companies which do not have continuous data were excluded from the sample. Therefore sample consist with 50 companies. Since the time period is 2012 to 2015 , the study has 200 observations.

This study do the content analysis (Note 1) of annual reports of quoted public banks and finance companies for the year 2012 to 2015 and the content analysis can be identified as the primary tool for analyze the annual reports. It can be defined as "A method of codifying text into different groups depending on selected criteria" (Weber, 1988). The content analysis is aimed to measure the level of voluntary disclosures of banking and finance companies. Voluntary disclosure index is developed, based on the indexes adopted and developed by Bhasin et.al. 2012; Ismail and El-Shaib 2012; Al-Shammari 2013; Haji and Ghazail 2013; Ho and Taylor 2013 and Charumathi and Ramesh 2015. Therefore the items are added based on those studies to provide empirical support of the index and each element is checked to eliminate the mandatory disclosures from the index. By considering all items are equally important this study used unweighted approach to score the items in disclosure index (Cooke; 1989; Hossain et.al., 1994; Wallace et al., 1994; Naser et.al. 2002; Ousama and Fatima; 2010) 
Analyzing the presence or absence of particular items of information is a most commonly used from of content analysis (Patten, 2002). Therefore, this study also analyze the present or absent of 83 disclosure items which are shown in Table 1 and the companies were awarded one (1) if the item is present and zero (0) if the item is absent. Thereafter, score of each item add together to calculate total for each company for each year and it compares with the maximum possible voluntary disclosures of the company (Leventis and Weetman, 2004). Therefore the index is calculated as follows.

Voluntary disclosure index $=$ Total of voluntary items/ Maximum possible voluntary items (83)

The above value has been taken as a measurement of dependent variable.

Table 1. Voluntary Disclosure Index

\section{A. Background about the Bank, Finance company or E.10 Disclosures on value-at-risk (VAR) Insurance company/ General Information (11)}

A.1. Brief narrative history of the bank/ Finance E.11. Maturity of foreign currency assets and liabilities company
A.2. Description of bank/ Finance company Structure
E.12. Maturity information about deposits and other liabilities

A.3. Description of major services

A.4. The legal form of the bank/ Finance company

F. Forward looking information (9)

A.5. Address of bank or Finance company/telephone/fax

F.1. Forecasts of cash flows

A.6. Bank / Finance company Website address

F.2. Forecasts of revenue

A.7. Email address

F.3. Economic influence to bank's or company's future

A.8. Date and details of establishment

F.4. Political influence to bank's or company's future

A.9. General Outlook of business activities

F.5. legal influence to bank's or company's future

A.10. List of branches location

F.6. Social influence to bank's or company's future

A.11. Information on branches/telephone/fax/ adders for F.7. Technological influence to bank's or company's correspondence future

\section{B. Corporate Strategy (6)}

F.8. Impact on strategies to the future performance

\begin{tabular}{|ll|}
\hline B. Corporate Strategy (6) & F.9. Discussion on future industry trend \\
\hline B.2. Corporate Mission & G. Human and Intellectual Capital (16) \\
\hline B.3. Corporate Goals and Objectives & G.1. Marketing innovation \\
\hline B.4. Corporate ethics & G.2. Brand values \\
\hline B.5. Corporate Values & G.3.Value of customer relationship \\
\hline B.6. Corporate Strategies & G.4.Value of patent/trademarks \\
\hline & G.5. RandD facilities \\
\hline C. Corporate Environment (5) & G.6.No. Of employees engaged in RandD \\
\hline C.1. General Outlook of the economic environment & G.7. RandD focus areas \\
\hline C.2. General Outlook of the industry environment & G.8.Total No. of employees \\
\hline C.3. General Outlook of the social environment & G.9. Category of employees by gender \\
\hline C.4. General Outlook of the legal environment & G.10. Policy on training \\
\hline C.5. General Outlook about the political environment & G.11. Category of employees undergoing training \\
\hline & G.12. Amount spent on employee training \\
\hline D. Financial Performance (10) & G.13. Equal opportunity policy statement \\
\hline $\begin{array}{l}\text { D.1 Brief discussion and analysis of a bank's / Finance } \\
\text { company's financial position. }\end{array}$ & G.14. Employee safety policies \\
\hline D.2. Qualitative forecast of earnings & G.15. Employee recruitment policy \\
\hline D.3. Return on equity & G.16.Human resources accounting \\
\hline D.4. Net interest margin & \\
\hline
\end{tabular}




\begin{tabular}{|c|c|}
\hline D.5. Earnings per share & H. Competitive Environment and Outlook (6) \\
\hline D.6. Risk weighted assets & H.1. Estimation of market size \\
\hline D.7. Debt to Equity ratio & H.2. Estimation of market growth \\
\hline D.8. Total liquid asset to assets ratio & H.3. Market share analysis \\
\hline D.9. Loan to deposit ratio & H.4.Barriers to entry \\
\hline \multirow[t]{2}{*}{ D.10 Dividend per share } & H.5.Competitive environment \\
\hline & H.6. Impact of competition on profit \\
\hline \multicolumn{2}{|l|}{ E. Risk Management (12) } \\
\hline E.1. Information on risk management committee & I. Corporate social responsibility (8) \\
\hline $\begin{array}{l}\text { E.2. Information on assets liability management } \\
\text { committee }\end{array}$ & $\begin{array}{l}\text { I.1. Sponsoring public health, sporting or recreational } \\
\text { projects }\end{array}$ \\
\hline E.3. Information on risk management structure & I.2. Information on donations to charitable organizations \\
\hline E.4. Information on credit management structure & $\begin{array}{l}\text { I.3. Supporting national pride/ government.- sponsored } \\
\text { campaigns }\end{array}$ \\
\hline E.5. Quantitative information on gross loan/deposits & I.4. Environmental protection program implemented \\
\hline $\begin{array}{l}\text { E.6. Amount and details of problem loans or details by } \\
\text { internal risk ratings }\end{array}$ & I.5. Awards for environmental protection \\
\hline E.7. Disclosure of credit rating system & I.6. Employee's appreciation \\
\hline E.8. Ageing schedule of past due loans and advances & I.7. Discussion of employees' welfare \\
\hline E.9. General descriptions of market risk segments & I.8. Statement of corporate social responsibility \\
\hline
\end{tabular}

Size, profitability, age, leverage, ownership concentration and board independence are taken as independent variables to the study and table 2 presents the operationalization of the variables which were developed based on the literature.

Table 2. Operationalization of variables

\begin{tabular}{|c|c|c|}
\hline $\begin{array}{l}\text { Independent } \\
\text { Variable }\end{array}$ & Measurement & Prior Studies support to the measurement of the study \\
\hline Size & Logarithm of total assets & $\begin{array}{l}\text { Owusu-Ansah 1998; Gul and Leung 2004; Lim et.al. 2007; } \\
\text { Bhasin et.al. 2012; Allegrini andGreco 2013; } \\
\text { Fri'as-Aceituno et al. 2014; Charumathi, B., and Ramesh, L. } \\
2015\end{array}$ \\
\hline Profitability & Net Profit/ Total Assets & $\begin{array}{l}\text { Meek et al., 1995;Allegrini and Greco 2013; Frı'as-Aceituno } \\
\text { et al. 2014; Charumathi and Ramesh } 2015\end{array}$ \\
\hline Age & Listing Age & $\begin{array}{l}\text { Owusu-Ansah 1998; Haniffa and Cooke 2002; Hammami } \\
\text { 2009; Uyar et.al. } 2013\end{array}$ \\
\hline Leverage & Debt/ Equity & $\begin{array}{l}\text { Leventis and Weetman, 2004; Allegrini andGreco 2013; } \\
\text { Charumathi and Ramesh } 2015\end{array}$ \\
\hline $\begin{array}{l}\text { Ownership } \\
\text { Concentration }\end{array}$ & $\begin{array}{l}\text { Percentage of total shares on } \\
\text { issue that were held by the } 20 \\
\text { largest shareholders. }\end{array}$ & Barako et al. 2006; Oliveira et al., 2006; White et al., 2007; \\
\hline $\begin{array}{l}\text { Board } \\
\text { Independence }\end{array}$ & $\begin{array}{l}\text { Number of non executive } \\
\text { independent directors on the } \\
\text { board as a percentage of the total } \\
\text { number of directors of the } \\
\text { company. }\end{array}$ & $\begin{array}{l}\text { Gul and Leung 2004; Barako et al. 2006; Cheng and } \\
\text { Courtenay 2006; Lim et.al. 2007; White et al., 2007; } \\
\text { Charumathi and Ramesh } 2015\end{array}$ \\
\hline
\end{tabular}

To examine the extent of voluntary disclosures, five categories are formulated based on the voluntary disclosure level (DL) as, $0<\mathrm{DL}\rangle=20$ - Very Little Extent, 20<DL $>=40$ - Little Extent, $40<$ DL $>=60$ - Some Extent, 60 $\langle\mathrm{DL}\rangle=80-$ Great Extent and $80<\mathrm{DL}\rangle=100$ - Very Great Extent.

To identify the determinants of voluntary disclosures panel data analysis (Note 2) used for the study. Firstly, by using $\mathrm{F}$ test it examines the group effects to see whether which model is best over from pooled Ordinary Least 
Square (OLS) and Fixed Effect (FE) model. This test carried out to see whether there is the fixed effect or not (Park, 2011), i.e. a test of the null hypothesis that all the firms share the same intercept against the alternative varies.

Secondly, it carries out Hausman test to see whether which model is best over from FE model and random effect model. The Hausman test compares the fixed and random effect models under the null hypothesis where unobservable effect is uncorrelated with any regressors of the model (Hausman, 1978).

Thirdly, it tests the existence of time fixed effect. Also the study tested the multi-collinearity by employing Variance Inflation Factor (VIF) and tolerance value. Furthermore cross sectional dependence, heteroskedasticity and serial correlation by employing pesaran's test of cross sectional dependence, modified wald test and Wooldridge test respectively for panel data to assure that the study used well behaved panel data and the null hypothesis of these tests are no cross sectional dependence, no heteroskedasticity and no serial correlation respectively.

Based on that following model is developed to the analysis.

$$
\mathrm{VD}_{\mathrm{it}}=\alpha_{\mathrm{it}}+\beta \mathrm{X}_{\mathrm{it}}+\eta_{\mathrm{i}}+v_{\mathrm{t}}+\varepsilon_{\mathrm{it}}
$$

Where,

$\mathrm{VD}_{\mathrm{it}}=$ Voluntary Disclosure Level for the i firm and $\mathrm{t}$ time

$\mathrm{X}_{\mathrm{it}}=$ determinants of voluntary disclosure level for the i firm and t time which consist with size, profitability (prof), age, Leverage (Lev), Ownership concentration (Own) and Board Independence (Ind).

$\eta_{\mathrm{i}}=$ The unobservable firm specific effect

$v_{\mathrm{t}}=$ Year fixed effect

\section{Analysis of Results}

This section analysis the data, results and findings of the study.

\subsection{The Extent of Voluntary Disclosure Level}

Firstly, this study analyze the extent of voluntary disclosure level of banking and finance companies with the focus of nine categories which are considered to measure the voluntary disclosure level and the extent of disclosure level explain as follows in each graph.

$$
\begin{aligned}
& \text { Values } \\
& \text {. Sum of Very Little Extent } \\
& \therefore \text { Sum of Little Extent } \\
& \text { III Sum of Some Extent } \\
& \text { " Sum of Great Exten } \\
& \text { * Sum of Very Great Extent }
\end{aligned}
$$

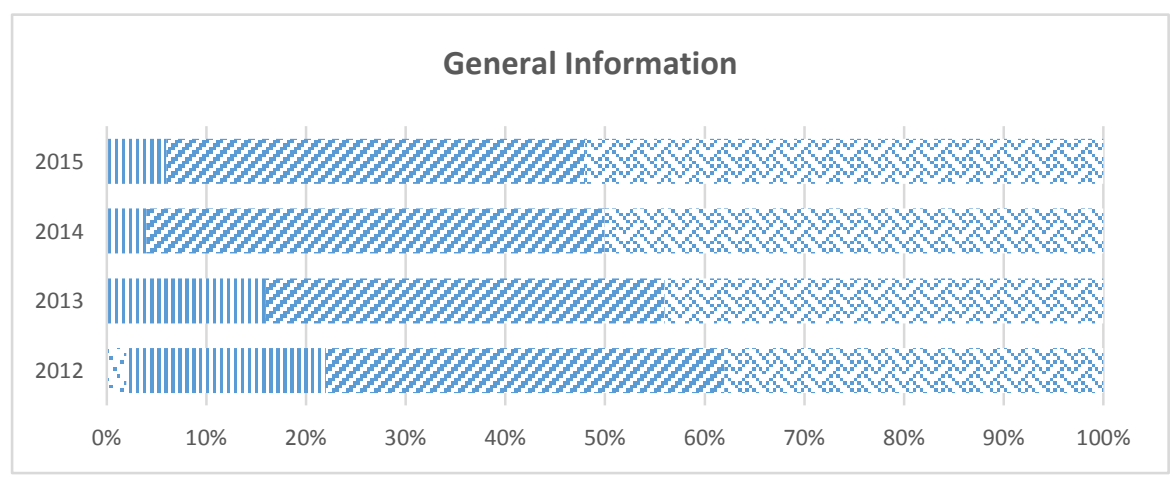

Figure 1. Disclosure level of General Information

Out of 50 companies, $99 \%$ are above the 'Little extent' level and no any company in the 'More Little extent' level. There is significant increase in Great extent and Very Great Extent categories, it has been increased from $78 \%$ to $94 \%$ from 2012 to 2015. 


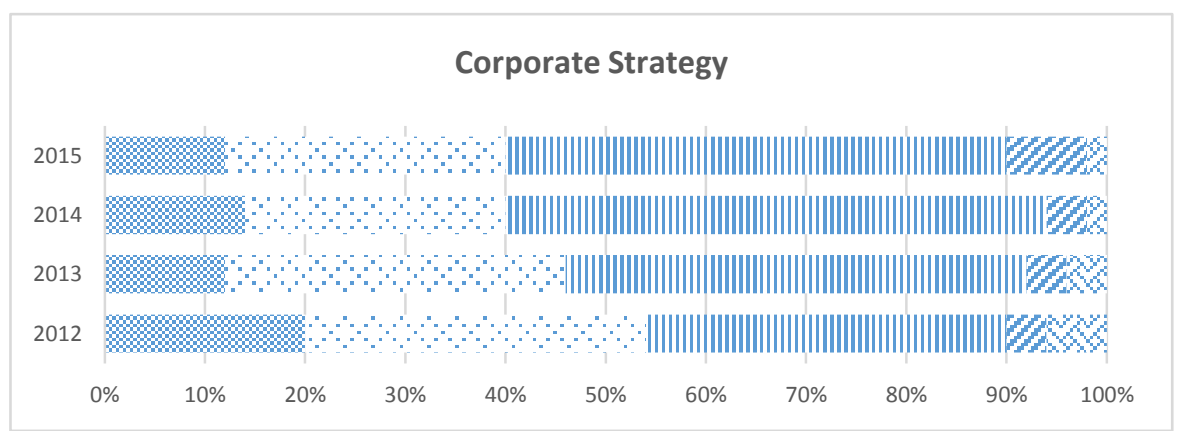

Figure 2. Disclosure level of Corporate Strategy

Majority of companies are in the poorer level of compliance, $91 \%$ companies are in underneath to the Great extent level. Disclosures level of the companies are 90\% in year 2012 and 2015, 92\% and 94\% in year 2013 and 2014 respectively. Close to this scenario Companies which are in great and very great extent are presenting $10 \%$ disclosing level in year 2012 and 2015, and also level of disclosing in 2013 and 2014 are 8\% and 6\% respectively.

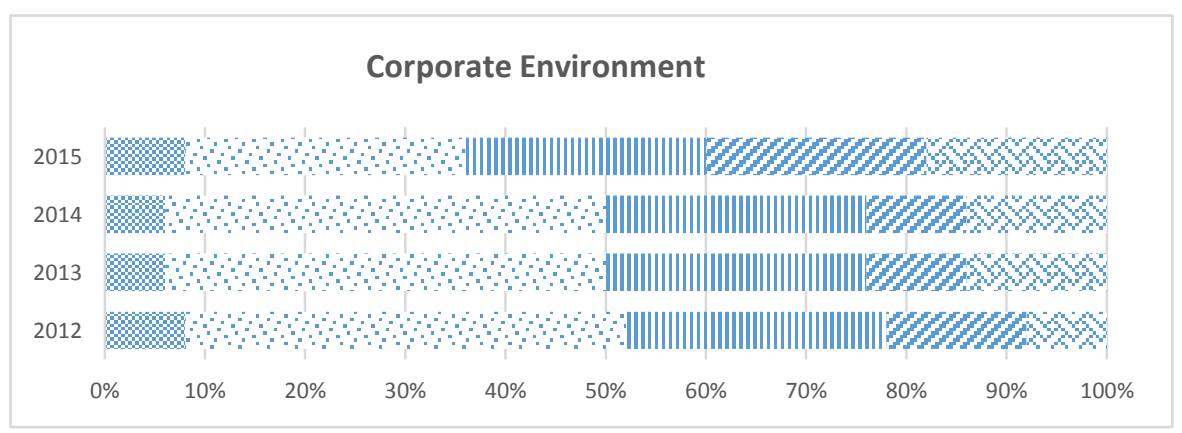

Figure 3. Disclosure level of Corporate Environment

Level of disclosures are $40 \%$ in the little extent category where others show 7\% (Very Little Extent), 26\% (Some extent), $14 \%$ each for great and Very great extent categories. Little extent level disclosures has decreased to $28 \%$ from $44 \%$ during considered period of time.

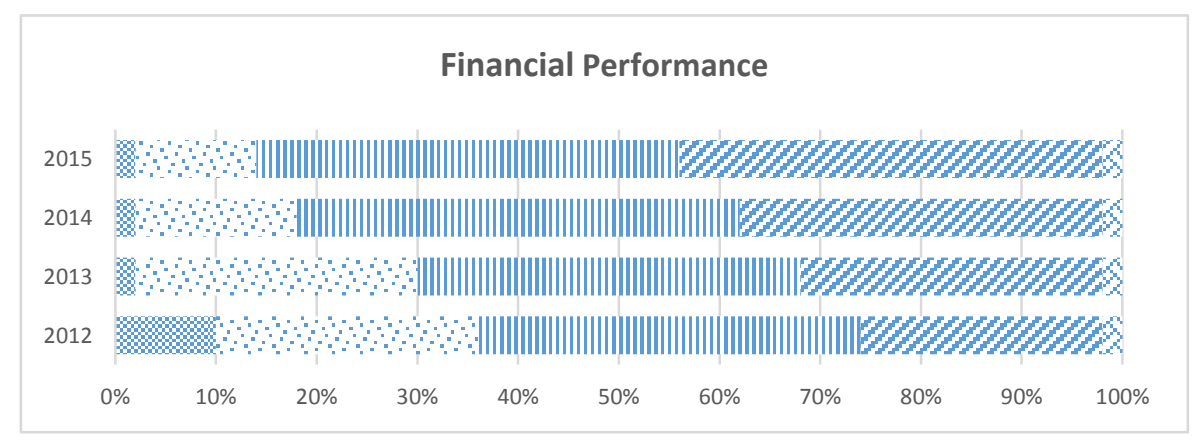

Figure 4. Disclosure level of Financial Performance

Degree of compliance 4\% and 2\% in Very Little extent and Very Great Extent categories, while $94 \%$ shows in little extent and grate extent categories. During the considerable period of time $2 \%$ constant disclosure level can be seen in the Very great extent category. Very little extent category shows 10\% discloser level in year 2012, it has drop down to $2 \%$ in year 2013 and then maintained same level in 2014 and 2015 also. 


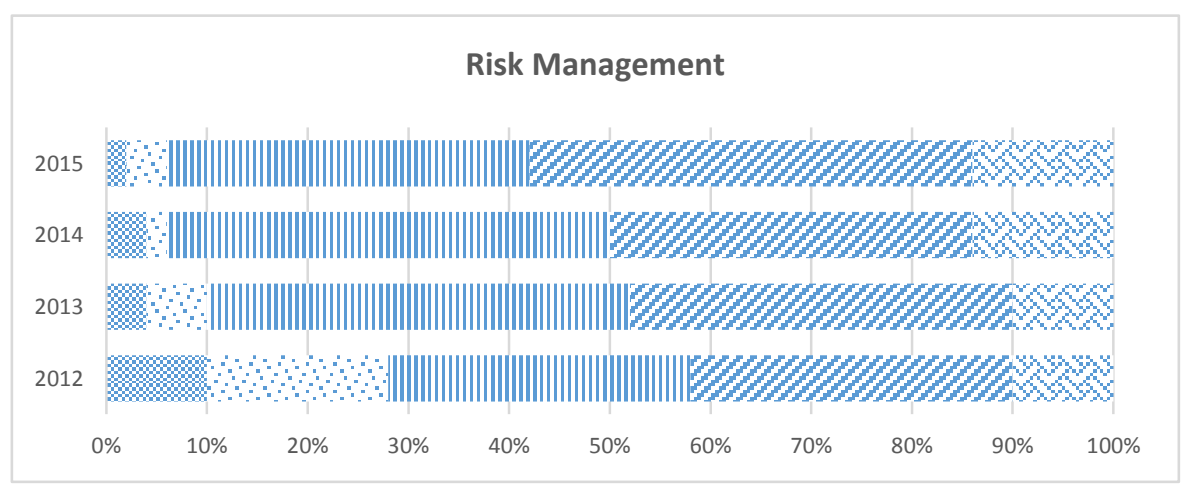

Figure 5. Disclosure level of Risk Management

Out of analyzed 50 companies $76 \%$ companies are in the level of some extent and great extent levels. It was $62 \%$ in year 2012 and it has been increased to $80 \%$ in immediate year, and maintained same percentage here after.

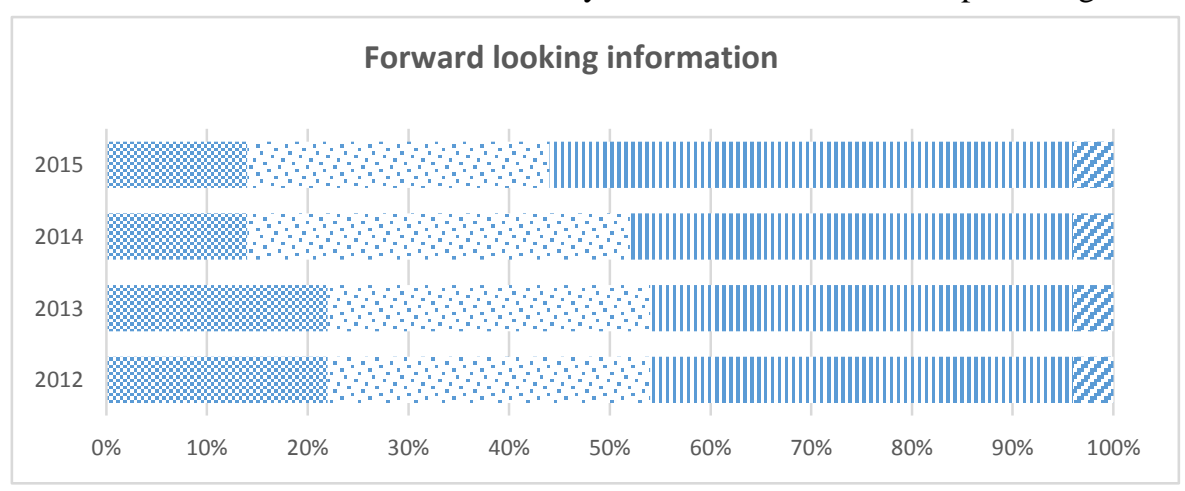

Figure 6. Disclosure level of forward looking information

It was observed that level of disclosures of Forward Looking Information are less. 96\% companies are in lesser than the Great extent category. No any company in the Very extent level in discloser category, and only $4 \%$ of the companies are in the Great extent level.

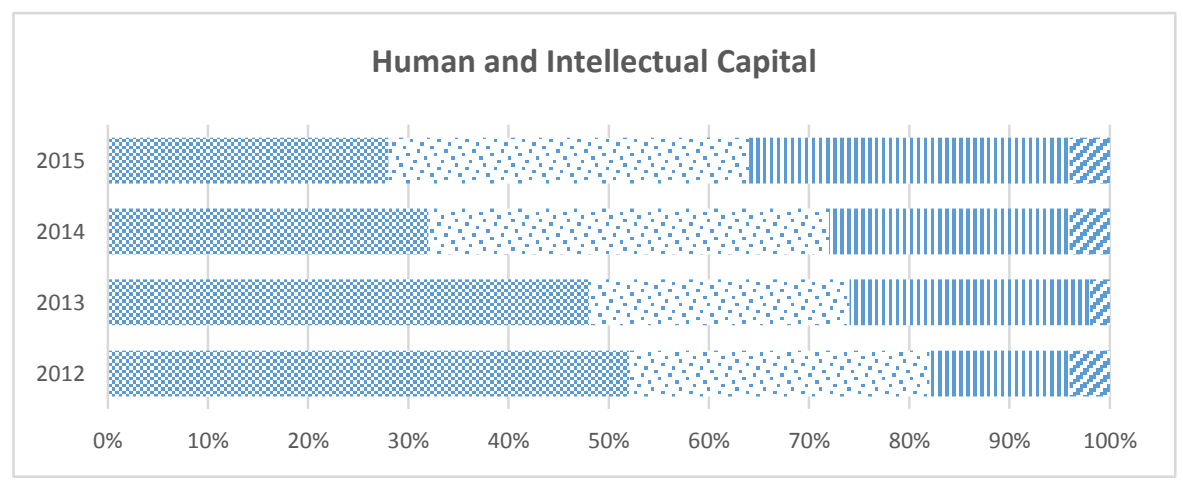

Figure 7. Disclosure level of Human and Intellectual Capital

Companies were failed to rank in Very great extent category and also only $3 \%$ companies from the sample were in the great extent category. Other companies ranked below to great extent level and it is 96\% for year 2012, 2014 and 2015 while 98\% disclosing level showing in the year 2013. 


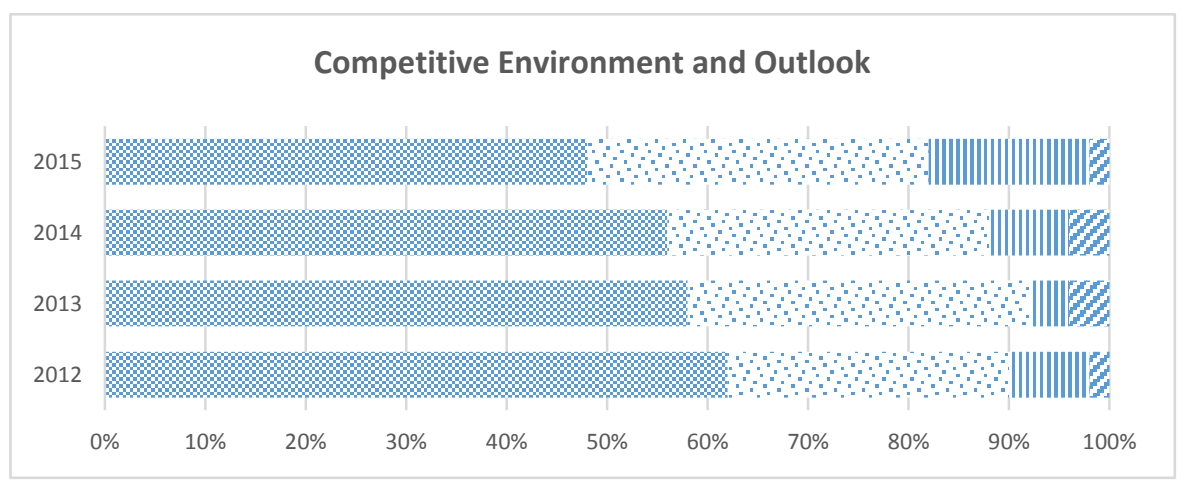

Figure 8. Disclosure level of Competitive Environment and Outlook

$88 \%$ from the sample was below to some extent level. From that $56 \%$ companies are in very little extent category. It was noted that disclosing level reduced up to $48 \%$ from 62\% during the period of 2012 to 2014.

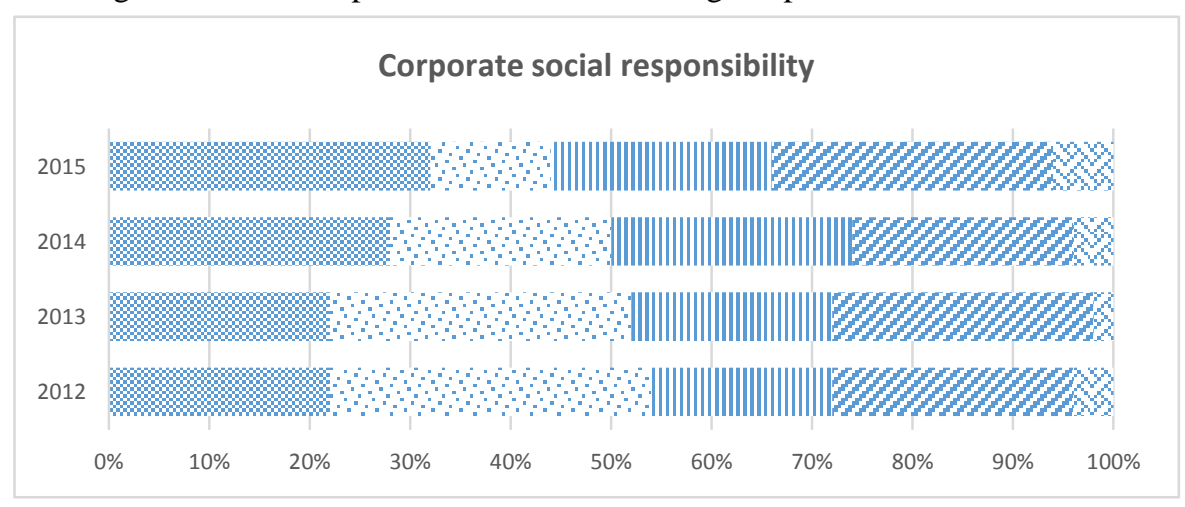

Figure 9. Disclosure level of Corporate Social Responsibility

Level of disclosing is $4 \%$ for very high extent, other $96 \%$ were distributed as follows; $26 \%, 24 \%, 21 \%$ and $25 \%$ for very little extent to Great extent respectively. Companies ranked below to the great extent level shows $96 \%$ disclosers level in year 2012, and it has been drop down to $92 \%$ in year 2015

Secondly, table 3 shows the number of disclosure item in each element disclosed by companies in 2012 and 2015 and it also presents the average disclosure items and percentage of disclosed items from all items of each content element. 
Table 3. Summary of voluntary disclosure level

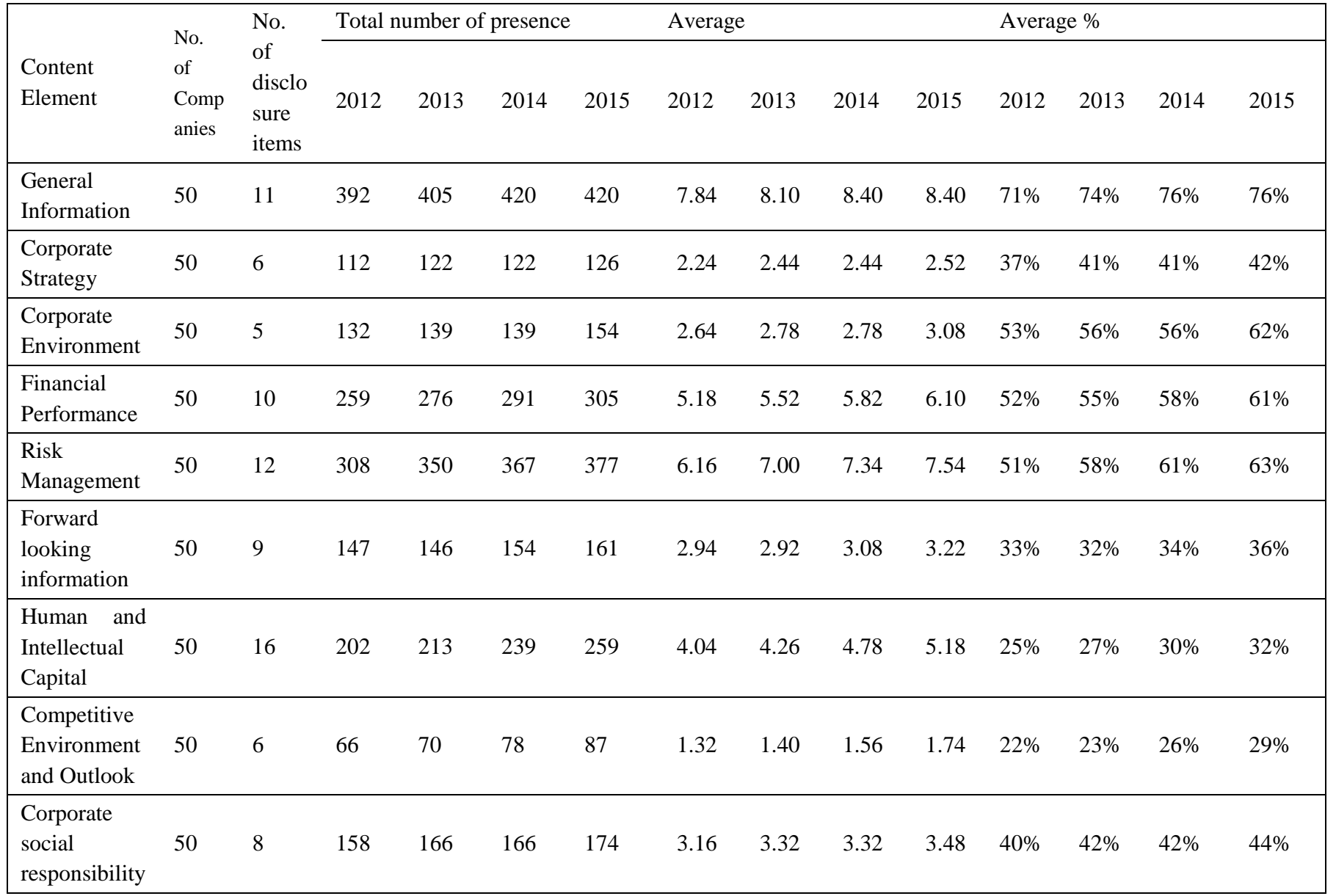

According to the results of empirical analysis we can conclude that there is increasing trend in voluntary disclosures throughout the considered period. As a whole, level of voluntary discloses was increased $42 \%$ to $49 \%$ for the duration of 2012 to 2014.

Highest average percentage can be seen in General information (71\%-2012 and 76\%-2015) while lowest average presenting in the 'Competitive environment and Outlook' (22\%-2012 to 29\%-2015). Banks and Finance companies have disclosed below mention information like Company history, structure, major services and other corporate information such as legal form, address, Telephone, Fax, Web details and particulars about branches other than facts regards Market details (Size, Growth and Share, entry barriers) and Competitive environment.

Corporate strategy, forward looking information, human and intellectual capital, competitive environment and outlook and corporate social responsibility information have less than $50 \%$ average.

When considering the average disclosing level throughout 2012 to 2015, highest increase can be seen in Risk Management disclosures that is $11 \%$ upturn with respect to year 2012 . There is only $3 \%$ increasing rate display for disclosures on Forward Looking Information. Increasing rate of other category of voluntary disclosers are as follows; 4\% for Corporate Social Responsibility, 5\% General information and Corporate Strategy and 7\% for discourses under the topics of Corporate Environment and Financial Performance. In places of Human and Intellectual Capital and Competitive Environment and Outlook shows 7\% rate while 9\% rate presenting Corporate Environment and Financial Performance.

\subsection{Determinants of Voluntary Disclosure Level}

Thirdly, F test and Hausman test carried out to identify the best model which should be used to identify the determinants of voluntary disclosures. $\mathrm{P}$ value of $\mathrm{F}$ test is 0.0000 leads to reject the null hypothesis i.e. there is no firm fixed effect. This result indicated that the fixed effect model was better than the pooled OLS model. Further, $\mathrm{p}$ value of hausman test is 0.0000 and therefore the null hypothesis of cross-section random effects is rejected. In this 
case, the fixed effect estimation is preferred to random effect model. Therefore the results confirmed that the fixed effect model is an appropriate method to identify the determinants of voluntary disclosures.

Furthermore to assure that the study used well behaved panel data firstly it test the multi-collinearity and VIF values are lie below 10 and tolerance values are lie above 0.10 and it indicate that each independent variable act independently. Since the P values are $0.1157,0.076$ and 0.087 for the results of Pesaran's Test of Cross-sectional Dependence, Modified Wald Test for Group Wise Heteroskedasticity and Wooldridge Test for Autocorrelation respectively, the study assured that there is no cross sectional dependence, no heteroskedasticity and no serial correlation.

Based on the identification of the best model, table 4 presents the empirical results of fixed effect model which used to identify the determinant of voluntary disclosures. (Note 3)

Table 4. Results of Fixed Effect Model

Periods included: 4

Cross-sections included: 50

Total panel (balanced) observations: 200

Dependent Variable: Voluntary Disclosure Level

\begin{tabular}{lllll}
\hline Variable & Coefficient & Std. Error & t-Statistic & Prob. \\
\hline C & -.7148192 & 0.1981063 & -3.61 & 0.000 \\
Size & 0.0582209 & 0.02214 & 2.63 & $0.009 * * *$ \\
Prof & 0.1357178 & 0480917 & 2.82 & $0.005^{* * *}$ \\
Age & 0.186925 & .0026669 & 7.01 & $0.000^{* * *}$ \\
Lev & -0.0020375 & .0007444 & -2.74 & $0.007^{* * *}$ \\
Own & 0.0495619 & .0569096 & 0.87 & 0.385 \\
Ind & -0.0552699 & .0324874 & 1.70 & $0.091^{*}$ \\
\hline
\end{tabular}

R-squared $=0.72$

Adj R-squared $=0.7032$

Note: Significant at: $* 10, * * 5$ and $* * * 1 \%$ levels

The firm's size, profitability and age are positively and strongly associated with voluntary disclosure level of the companies and provides strong support for $\mathrm{H} 1, \mathrm{H} 2$ and $\mathrm{H} 3$. Leverage is significant but there is a negative relationship and this does not support to the positive relationship expected in H4. Although it has the expected positive sign, ownership concentration variable lacks statistical significance and therefore H5 is not supported. Furthermore, the board independence is a significant determinant and it has positive relationship. However, this result is not consist with the expected sign of the hypothesis and therefore H6 is not supported.

\section{Discussion}

These extent of voluntary disclosure level implies that companies reveal the information which they can easily find and there is a lack of forward looking information and Competitive environment and Outlook. Due to this deficiency in disclosures investors and other stakeholders cannot measure value of the company and what, investors can earn by investing particular company. And Lack of voluntary disclosure by companies could be attributed to absence of encouragement and pressures from stakeholders (Al-Shammari, 2013). Therefore, those who are responsible for the corporate reporting should consider about the elements which have lacking disclosure level and should take necessary actions to improve those areas to give better output to the all stakeholders. As per the Nazil and Ghazali (2008) findings, some companies are willing to share information only to selected interested parties during their private meetings than in a public document. Therefore, this also may be the factor to have lack of some information in annual reports.

The firm size, profitability and age are supported to the theoretical expectation of agency theory. The significant positive sign of the firm's size which is consisting with the many of prior studies indicate that the companies having 
large firm size will tend to disclose more voluntary disclosures. It mean that small firms have less voluntary disclosure level. Since, disclosing information is a costly process and therefore smaller firms may not be afford such costs Owusu-Ansah 1998. Furthermore, there are some other points have been pointed out by the previous studies to have positive relationship among size and the voluntary disclosure level. Since larger firms have required resources and expertise to produce and publish sophisticated financial statements, they disclose more information (Ahmed and Nicholls, 1994), small firms fear competition and therefore they are tended to disclose less information than their larger competitive firms (Craswell and Taylor, 1992; Wallace et al., 1994, pressure which comes from the stakeholders is more in larger firms than smaller firms to disclose more voluntary disclosures (Habbash et.al. 2016).

There are some reasons to have positive relationship between profitability and voluntary disclosure level such as higher profitability tend be a motive to managers to provide more voluntary disclosures (Leventis and Weetman, 2004; Iatridis and Alexakis, 2012), higher profitability firms are likely to signal to their success to the market through high level of disclosures (Wallace et.al., 1994).

The positive relationship between age and voluntary disclosure level suggested that the older firms have resources than small firms which required to disclose voluntary information. Also they may believe that disclosing more information will not be affect to lose their competitive advantage.

The result of leverage as a determinant is consisted with the findings of Uyar et.al. 2013 and Habbash et.al. 2016 but contradicts with the expectations of the agency theory. When debt level of firm is high, to protect their competitive position in the market they tend to disclose less information and this may be the fact to have this type of relationship (Uyar et.al. 2013). Furthermore, this direction may be due to management fear of unfavorable forecasts and pressure which comes from the lenders because of the increasing risk (Watson et.al. 2002).

Ownership concentration is not a determinant of voluntary disclosure level and the finding contradict with the expectation of agency theory and consist with the findings of Craswell and Taylor (1992).

Although a significant predictor, the result for board independence is not in the direction predicted. Even though Habbash et.al. 2016 find board independence as insignificant factor to determine the voluntary disclosure level, the direction was supported with the findings of this study. Therefore this result suggested that the increased monitoring by independent directors will be reason to reduce voluntary disclosure level. Furthermore, the results are not supported to the agency theory which identified that board independence influence to increase the voluntary disclosure level.

\section{Conclusion}

There is no argument that voluntary disclosures are important for the firm itself as well as the other interested stakeholders. Because, stakeholders prefer to have enhanced reporting structure of companies which provide more voluntary disclosures and it will help them to make more informed assessment of companies and ultimately make better decisions. On the other hand, if companies provide more voluntary information it will enhance their reputation through the transparent reporting framework.

With the identification of importance of voluntary disclosure notion, this study explores the extent of voluntary disclosure level and its determinants of the quoted public banking companies in Sri Lanka.

The findings of extent of voluntary disclosure level indicate that there is a small improvement of voluntary disclosure level in all nine aspects compared 2015 with 2012. However, there is no significant improvement. The finding provide evidence that companies have lack voluntary disclosures in some areas and factors which affect to the voluntary disclosure level. Therefore this will helpful to management to get idea about their disclosure level and to improve their overall disclosure practices. Furthermore, the degree of extent of voluntary disclosure level of companies suggested that, if firms want to get advantages from voluntary disclosures they should give their attention to the lacking areas of disclosures and should take remedial actions to improve those areas.

Furthermore, the study found that the voluntary disclosure level of banking and finance companies depends on some factors such as firm size, profitability and age, leverage and board independence. However, ownership concentration was found as insignificant factor. Therefore from the findings of this study stakeholders also can get idea about the disclosure practices in the banking and finance industry to make superior decisions.

Notwithstanding the findings, the current study does have limitations, which point to potentially fruitful research opportunities. The study selected only quoted public banking and finance companies. Further, this study measure the voluntary disclosure practices only in annual reports and it ignores the information publish in other sources such as company's web site, newspaper articles, financial presses, conference calls, stock market announcements etc. 
Furthermore, future studies can focus to identify the extent and determinants of integrated reporting which can be treated as a new form of voluntary disclosure.

\section{References}

Abdullah, A., \& Ku Ismal, K.N.I. (2008). Disclosure of voluntary accounting ratios by Malaysian listed companies. Journal of Financial Reporting and Accounting, 6(1), 1-20. http://dx.doi.org/10.1108/19852510880000632

Ahmed, K., \& Nicholls, D. (1994). The impact of non-financial company characteristics on mandatory disclosure in developing countries: The case of Bangladesh. International Journal of Accounting Education and Research, 29(1), 62-77.

Al-Shammari, B. (2013). An investigation of voluntary disclosure by Kuwaiti Shariah-compliant companies. Journal of Economic and Administrative Sciences, 29(1), 21 - 41. http://dx.doi.org/10.1108/10264111311319213

Barako, D. G., Hancock, P., \& Izan, H. Y. (2006). Factors influencing voluntary corporate disclosure by Kenyan companies. Corporate Governance: An International Review, 14(2), 107-125. http://dx.doi.org/10.1111/j.1467-8683.2006.00491.x

Beasley, M. (1996). An empirical analysis of the relation between the board of director composition and financial statement fraud. The Accounting Review, 71(4), 443-465.

Bhasin, M.L., Makarav, R.R., \& Orazalin, N.S. (2012), Determinants of Voluntary Disclosure in the Banking Sector: An Empirical Study. International Journal of Contemporary Business Studies, 3(3), 60-70.

Bowman, E. H. (1982). Risk seeking by troubled firms. Sloan Management Review, 23(4), 33-42.

Bowman, E. H. (1984). Content analysis of annual reports for corporate strategy and risk. Interfaces, 14, 61-71. http://dx.doi.org/10.1287/inte.14.1.61

Cerf, A.R. (1961). Corporate Reporting and Investment Decisions, University of California Press, California, CA.

Charumathi, B., \& Ramesh, L. (2015). On the Determinants of Voluntary Disclosure by Indian Companies. Asia-Pacific Journal of Management Research and Innovation, 11(2), 108-116. https://dx. doi: 10.1177/2319510X15576179

Cooke, T.E. (1989). Disclosure in the corporate annual reports of Swedish companies. Accounting \& Business Research, 19(74), 113-124. http://dx.doi.org/10.1080/00014788.1989.9728841

Cooke, T.E. (1992). The impact of size, stock market listing and industry type on disclosure in the annual reports of Japanese listed corporations. Accounting \& Business Research, 22(87), 229-237. http://dx.doi.org/10.1080/00014788.1992.9729440

Craswell, A. T. \& Taylor, S. L. (1992). Discretionary Disclosure of Reserves by Oil and Gas Companies: An Economic Analysis. Journal of Business Finance and Accounting, 19, 295-308. http://dx.doi.org/10.1111/j.1468-5957.1992.tb00626.x

Elliott, R.K. \& Jacobson, P.D. (1994). Costs and benefits of business information disclosure: a commentary, Accounting Horizon, 8, 80-96. http://dx.doi=10.1.1.364.5227

Eng,L.L \& Mak, Y.T. (2003). Corporate governance and voluntary disclosure. Journal of Accounting and Public Policy, 22, 325-345. http://dx.doi.org/10.1016/S0278-4254(03)00037-1

Fama, E. F. \& Jensen, M. C. (1983). Separation of ownership and control. The Journal of Law and Economics, 25(2), 301-325. http://dx.doi.org/10.1086/467037

Forker, J.J. (1992), Corporate Governance and Disclosure Quality. Accounting and Business Research, 22(86), 111-124. http://dx.doi.org/10.1080/00014788.1992.9729426

Gouws, D.G \& Cronje, C.J. (2008). Corporate annual reports: accounting practices in transition. Southern African Business Review, 12(2), 108-133.

Gul, F. A. \& Leung, S. (2004). Board leadership, outside directors' expertise and voluntary corporate disclosures. Journal of Accounting and public Policy, 23(5), 351-379. http://dx.doi.org/10.1016/j.jaccpubpol.2004.07.001

Habbash, M.,Hussainey, K. and Awad, A.E. (2016) 'The determinants of voluntary disclosure in Saudi Arabia: an empirical study', Int. J. Accounting, Auditing and Performance Evaluation, 12(3), 213-236. http://dx.doi.org/10.1504/IJAAPE.2016.077890 
Haji, A.A. \& Ghazail, N.A.M. (2013), The quality and determinants of voluntary disclosures in annual reports of Shari'ah compliant companies in Malaysia, Humanomics, $29(1), \quad 24 \quad-\quad 42$. http://dx.doi.org/10.1108/08288661311299303

Haniffa, R.M. \& Cooke, T.E (2002). Culture, corporate governance and disclosure in Malaysian corporations, ABACUS, 38(3), 317-350. http://dx.doi.org/10.1111/1467-6281.00112

Hausman, A.J. (1978). Specification Tests in Econometrics, Econometrica, 46, 1251-1271. http://dx.doi.org/10.2307/1913827

Hausman, A.J. \& Taylor, E.W. (1981). Panel Data and Unobservable Individual Effect, Econometrica, 49(6), 1377-1398. http://dx.doi.org/10.2307/1911406

Ho, P.L, \& Taylor, G. (2013). Corporate governance and different types of voluntary disclosure: Evidence from Malaysian listed firms. Public Accounting Review, 25(1), 4-29. http://dx.doi.org/10.1108/01140581311318940

Hossain, M., Tan, L.M. \& Adams, M. (1994), Voluntary disclosure in an emerging capital market: some empirical evidence from companies listed on the Kuala Lumpur Stock Exchange. The International Journal of Accounting, 29(4), 334-351.

Hossain, M., \& Hammami, H. (2009). Voluntary disclosure in the annual reports of an emerging country: The case of Qatar. Advances in Accounting, 25(2), 255-265. http://dx.doi.org/10.1016/j.adiac.2009.08.002

Huafang, X. \& Jianguo, Y. (2007). Ownership structure, board composition and corporate voluntary disclosure, Managerial Auditing Journal, 22(6), 604 - 619. http://dx.doi.org/10.1108/02686900710759406

Iatridis, G., \& Alexakis, P. (2012). Evidence of voluntary accounting disclosures in the Athens Stock Market, Review of Accounting and Finance, 11(1), 73-92. http://dx.doi.org/10.1108/14757701211201830

Inchausti, B. G. (1997). The influence of company characteristics and accounting regulation on information disclosed by Spanish firms. European Accounting Review, 6(1), 45-68. http://dx.doi.org/10.1080/096381897336863

Ismail, T.H., \& El-Shaib, N.M. (2012). Impact of market and organizational determinants on voluntary disclosure in Egyptian companies, Meditari Accountancy Research, 20(2), 113 - 133. http://dx.doi.org/10.1108/10222521211277825

Jensen, M.C., \& Meckling, W. (1976). Theory of the firm: Managerial behavior, agency costs and capital structure. Journal of Financial Economics 3, 305-360. http://dx.doi.org/10.2139/ssrn.94043

Kristandl, G., \& Bontis, N. (2007). The impact of voluntary disclosure on cost of equity capital estimates in a temporal setting. Journal of Intellectual Capital, 8(4), 577-594. http://dx.doi.org/10.1108/14691930710830765

Leventis, S., \& Weetman, P. (2004). Impression management: dual language reporting and voluntary disclosure, Accounting Forum, 28, 307-328. http://dx.doi.org/10.1016/j.accfor.2004.07.004

Lim, S., Matolcsy, Z., \& Chow, D. (2007). The association between board composition and different types of voluntary disclosure, European Accounting Review, 16(3), 555-583. http://dx.doi.org/10.1080/09638180701507155

Meek, G.K., Roberts, C., \& Gray, S.J. (1995). Factors Influencing Voluntary disclosure Annual Report Disclosures by U.S., U.K. and Continental European Multinational Corporations. Journal of International Business Studies, 96(3), 555-572. http://dx.doi.10.1057/palgrave.jibs.8490186

Naser, K., Alkhatib, K., \& Karbhari, Y. (2002), Empirical evidence on the depth of corporate information disclosure in developing countries: the case of Jordan. International Journal of Commerce \& Management, 12, 122-34. http://dx.doi.10.1108/eb047456

Nazli, A.M.G. (2008). Voluntary disclosure in Malaysian corporate annual reports: views of stakeholders. Social Responsibility Journal, 4(4), 504 - 516. http://dx.doi/abs/10.1108/17471110810909902

Oliveira, L., Rodrigues, L.L., \& Craig, R. (2006). Firm-specific determinants of intangibles reporting: evidence from the Portuguese stock market. Journal of Human Resources Costing, 10(1), 11-33. http://dx.doi.org/10.1108/14013380610672657

Owusu-Ansah, S. (1998). The Impact of Corporate Attributes on the Extent of Mandatory Disclosure and Reporting by Listed Companies in Zimbabwe, 33(5), 605-631. https:// dx.doi. 10.1016/S0020-7063(98)90015-2 
Ousama, A.A, \& Fatima, A.H. (2010). Voluntary disclosure by Shariah approved companies: an exploratory study. Journal of Financial Reporting and Accounting, 8(1), 35 - 49. http://.dx.doi.10.1108/19852511011055943

Park, H.M. (2011). Practical Guides To Panel Data Modeling: A Step by Step Analysis Using Stata, Tutorial Working Paper, Graduate School of International Relations, International University of Japan.

Patten, D.M. (2002). The relation between environmental performance and environmental disclosure: a research note. Accounting, Organizations and Society, 27(8), 763-773. http://.dx.doi.10.1016/S0361-3682(02)00028-4

Ramanauskaite, A., \& Laginauskaitè, M.R. (2014). Disclosure on Intellectual Capital in Annual Reports of NASDAQ OMX Baltic-Listed Companies. Ekonomika, 93(4), 135-156.

Ross, S.A. (1973). The economic theory of agency: The principals' problems. American Economic Review, 63(2), 134-139.

Souissi, M., \& Khlif, H. (2012). Meta-analytic review of disclosure level and cost of equity capital. International Journal of Accounting and Information Management, 20(1), 49-62. http://dx.doi.org/10.1108/18347641211201072

Wallace R.S.O., Naser, K. \& Mora A. (1994). The relationship between the comprehensiveness of corporate annual reports and firm characteristics in Spain. Accounting and Business Research, 25(97), 41-53. http://dx.doi.org/10.1080/00014788.1994.9729927

Watson, A., Shrives, P., \& Marston, C. (2002). Voluntary Disclosure of Accounting Ratios in the UK. The British Accounting Review, 34(4), 289-313. http://dx. doi:10.1006/S0890-8389(02)00077-X

Weber, R.P. (1988). Basic Content Analysis, Sage University Paper Series on Quantitative Applications in the Social Sciences, Series No. 07-049, Sage, Beverly Hills, CA, and Lond.

White, G., Lee, A., \& Tower, G. (2007). Drivers of voluntary intellectual capital disclosure in listed biotechnology companies. Journal of Intellectual Capital, 8(3), 517-537. http://dx.doi.org/10.1108/14691930710774834

Uyar, A., Kilic, M., \& Bayyur, N. (2013). Association between firm characteristics and corporate voluntary disclosure: Evidence from Turkish listed companies. Intangible Capital, 9(4), 1080-1112. http://dx.doi.org/10.3926/ic.439

\section{Notes}

Note 1. Studies such as Bowman (1982), Bowman (1984), Gouws and Cronje (2008), Ramanauskaite and Laginauskaite (2014) used content analysis to study the annual report disclosures of various organizations.

Note 2. According to Hausman \& Taylor (1981) an important benefit that can be obtained from panel data is that it has ability to account for individual-specific effects which are possibly unobservable and which may be correlated with other included variables in the specification of an economic relationship. Therefore, to obtain this benefit this study employ the panel data analysis to identify the determinants of voluntary disclosure level.

Note 3. STATA software is used to do all the specifications test which are carried to identify the best model and to analyze results of fixed effect model. 